\title{
Associations between ambient air pollution and cancer incidence in Taiwan: an ecological study of geographical variations
}

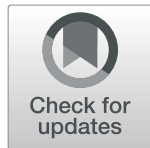

\author{
Shih-Yung Su ${ }^{1,2}$, Yung-Po Liaw³, Jing-Rong Jhuang ${ }^{1}$, Shu-Yi Hsu ${ }^{3}$, Chun-Ju Chiang ${ }^{1,4}$, Ya-Wen Yang ${ }^{4}$ and
} Wen-Chung Lee ${ }^{1,2,4^{*}}$ (D)

\begin{abstract}
Background: Air pollution is a global public health concern. The World Health Organization has recently set up a goal of saving 7 million people globally by 2030 from air pollution related death. We conducted an ecological study of geographical variation to explore the association between air pollution (specifically, particulate matter < $2.5 \mu \mathrm{m}$ in aerodynamic diameter $\left[\mathrm{PM}_{2.5}\right]$, particulate matter $<10 \mu \mathrm{m}$ in aerodynamic diameter, sulfur dioxide, nitrogen dioxide, nitric oxide, and ozone) and cancer incidence in Taiwan, from 2012 to 2016.
\end{abstract}

Methods: In this study, the yearly average concentrations of each air pollutant at 75 air quality monitoring stations were calculated, and using the kriging method, the concentrations were extrapolated to each and every geographical central point of 349 local administrative areas of Taiwan. Spearman rank correlation coefficients between the age-adjusted cancer incidence rates and various air pollutants were calculated by stratifying genders and urbanization degrees of the local administrative areas. A total of 70 correlation coefficients were calculated.

Results: In total, 17 correlation coefficients were significantly positive at an alpha level of 0.05 . Among these, four correlation coefficients between the age-adjusted cancer incidence rates and $\mathrm{PM}_{2.5}$ levels remained significant after Bonferroni correction. For men in developing towns, general towns, and aged towns and for women in aged towns, the age-adjusted cancer incidence rates increased 13.1 (95\% confidence interval [Cl], 8.8-17.6), 11 (95\% Cl, 5.6-16.4), 16.7 (95\% Cl, 6.9-26.4), and 11.9 (95\% Cl, 5.6-18.2) per 100,000 populations, respectively, for every $1 \mu \mathrm{g} / \mathrm{m}^{3}$ increment in $\mathrm{PM}_{2.5}$ concentrations.

Conclusions: A significantly positive correlation was observed between the $\mathrm{PM}_{2.5}$ level and cancer incidence rate after multiple testing correction.

Keywords: Cancer, Incidence, Air pollution, Kriging method, Correlation, Geographical variation

\section{Background}

Air pollution is a major public health concern. In 2005, the World Health Organization (WHO) announced air quality guidelines for outdoor air pollution, including annual and daily permissible levels for fine particulate matter (particulate matter $<2.5 \mu \mathrm{m}$ in aerodynamic diameter $\left.\left[\mathrm{PM}_{2.5}\right]\right)$, coarse particulate matter (particulate matter $<10 \mu \mathrm{m}$ in

\footnotetext{
* Correspondence: wenchung@ntu.edu.tw

1 Institute of Epidemiology and Preventive Medicine, College of Public Health, National Taiwan University, Taipei, Taiwan

${ }^{2}$ Innovation and Policy Center for Population Health and Sustainable Environment, College of Public Health, National Taiwan University, Taipei, Taiwan

Full list of author information is available at the end of the article
}

aerodynamic diameter $\left.\left[\mathrm{PM}_{10}\right]\right)$, sulfur dioxide $\left(\mathrm{SO}_{2}\right)$, nitrogen dioxide $\left(\mathrm{NO}_{2}\right)$, and ozone $\left(\mathrm{O}_{3}\right)$ [1]. In 2018, WHO hosted the first conference on air pollution and health, and set up a goal of saving 7 million people globally by 2030 from death due to air pollution [2].

Air pollution is associated with cardiovascular diseases [3], chronic obstructive pulmonary disease [4], and specific types of cancers, such as oral, lung, breast, liver, bladder, kidney, prostate and ovarian [5-18], and is estimated to cause 4.2 million premature deaths globally [19]. Moreover, outdoor air pollution has been classified as a Group 1 carcinogen (carcinogenic to

(c) The Author(s). 2019 Open Access This article is distributed under the terms of the Creative Commons Attribution 4.0 International License (http://creativecommons.org/licenses/by/4.0/), which permits unrestricted use, distribution, and reproduction in any medium, provided you give appropriate credit to the original author(s) and the source, provide a link to the Creative Commons license, and indicate if changes were made. The Creative Commons Public Domain Dedication waiver (http://creativecommons.org/publicdomain/zero/1.0/) applies to the data made available in this article, unless otherwise stated. 
humans) by the International Agency for Research on Cancer (IARC) [20].

Through an ecological study, the association between air pollution and disease morbidity can be conveniently explored, and the results can be used to establish measures to quickly respond to the urgent public health concerns. We took an integrated approach and conducted an ecological study of geographical variation to explore the association between air pollution and incidence of all types of cancer in Taiwan.

\section{Methods}

All incident cancer cases from 2012 to 2016 were extracted from the Taiwan Cancer Registry database. Cancer cases were categorized based on gender, age (seven age groups: $20-29,30-39,40-49,50-59,60-69,70-79$, and $\geq 80$ years), and residence (a total of 349 local administrative areas [LAAs], excluding the 19 LAAs in offshore islands). We excluded cases in which patients aged less than 20 years because of the paucity of data. Population numbers from 2012 to 2016 were extracted from an online database provided by the Department of Statistics of the Ministry of the Interior in Taiwan and were similarly classified. Because the age structures of the LAAs are disparate, the age-adjusted cancer incidence rates were calculated using the 2000 World Standard Population proportions from WHO.

Air pollution monitoring data from 2012 to 2016 were provided by the Environmental Protection Administration of Taiwan. A total of 75 air quality monitoring stations (all located in the main island of Taiwan) monitored hourly concentrations of $\mathrm{PM}_{2.5}, \mathrm{PM}_{10}, \mathrm{SO}_{2}$, nitric oxide, $\mathrm{NO}_{2}$, and $\mathrm{O}_{3}$. However, we calculated the coarser yearly average concentrations of each air pollutant at these monitoring stations because the data of these stations may be lacking for several months during a year due to regular maintenance. Subsequently, the kriging method [21] was used to extrapolate these concentrations, based on the spatial correlations between air quality monitoring stations, to each and every geographical central point of all 349 LAAs (the longitudes and latitudes of which were taken from the online data provided by the National Land Surveying and Mapping Center of the Ministry of the Interior in Taiwan). Gaussian, exponential, Matérn, spherical, cubic, pentaspherical, and hole-effect models were fit to the semivariograms (a spatial correlation function of the distance between stations), constructed for station pairs with distances less than $50 \mathrm{~km}$ (a total of 640 pairs), and the best-fit model was selected (the smallest sum of squared errors). Ordinary kriging equations were used for interpolations. We assumed that the exposure levels of outdoor air pollution for people from the same LAA were the same for all age groups.
We calculated Spearman rank correlation coefficients between the age-adjusted cancer incidence rates and various air pollutants by stratifying genders and urbanization degrees of the LAAs. Gender stratification should reduce some of the confounding effects of tobacco smoking as the smoking prevalence in Taiwan is strongly gender-dependent (Additional file 1: Table S1). The urbanization degree was defined based on demographic characteristics (such as population density, education level, and the proportion of elderly people), industrialization, and medical resources in each LAA. A total of seven urbanization degrees were defined: metropolises, cities, developing towns, general towns, aged towns, agriculture towns, and villages [22]. A total of 70 hypotheses were tested, and Bonferroni correction was used for counteracting the multiple testing problem. All statistical analyses (including the kriging method) were conducted using SAS software 9.4 version (SAS ${ }^{\circ}$ Institute Inc., Cary, North Carolina, USA). QGIS software 3.6 version (QGIS Development Team, n.d.) was used to draw maps.

This study was approved by the Data Release Review Board of the Health Promotion Administration, Ministry of Health and Welfare in Taiwan, which waived the requirement for informed consent.

\section{Results}

Nineteen cities/counties in the main island of Taiwan are listed in Fig. 1. The same figure also presents the 349 LAAs (classified into seven urbanization degrees) and the 75 air quality monitoring stations. Among the 349 LAAs, 27 LAAs were metropolises (7.7\%), 42 were cities (12\%), 57 were developing towns (16.3\%), 85 were general towns $(24.4 \%), 31$ were aged towns $(8.9 \%), 60$ were agricultural towns (17.2\%), and 47 were villages (13.5\%). The metropolises and cities were mainly located in northern and western Taiwan, whereas agricultural towns and villages were located in the central mountain range. The air quality monitoring stations were distributed throughout the main island, but were concentrated in northern and western Taiwan.

The age-adjusted cancer incidence rates for men and women from 2012 to 2016 in the 349 LAAs are presented in Fig. 2. For men, the age-adjusted rates in $82.2 \%$ of the LAAs in southwestern and midwestern Taiwan were higher than 528.3 (the median of Taiwan) per 100,000 population. Eleven LAAs in Kaohsiung City, five in Tainan City, four in Pingtung County, four in Yunlin County, and three in Chiayi County had the highest (top 10\%) age-adjusted rates. For women, the LAAs with the highest age-adjusted rates were located in southwestern (11 LAAs in Tainan City, 7 in Kaohsiung City, 4 in Pingtung County, and 1 in Chiayi County), 


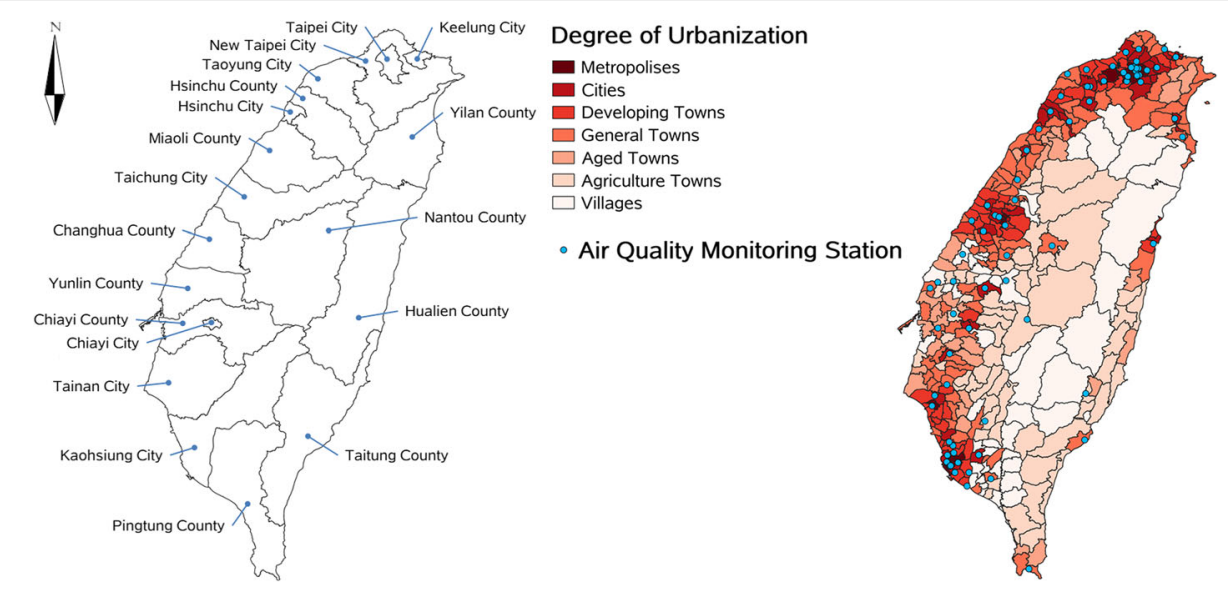

Fig. 1 The 349 local administrative areas, 75 monitoring stations and 7 degrees of urbanization

midwestern (4 LAAs in Taichung City), and northern (4 LAAs in New Taipei City) Taiwan.

The distribution of yearly air pollution concentrations at the 75 air quality monitoring stations from 2012 to 2016 is presented in Table 1. The mean (minimum and maximum) concentrations of $\mathrm{PM}_{2.5}, \mathrm{PM}_{10}, \mathrm{SO}_{2}, \mathrm{NO}_{\mathrm{x}}$ (the combination of $\mathrm{NO}$ and $\mathrm{NO}_{2}$ ), and $\mathrm{O}_{3}$ were 25.2 (6.3 and 45.4) $\mu \mathrm{g} / \mathrm{m}^{3}, 49.5(15.7$ and 81.9$) \mu \mathrm{g} / \mathrm{m}^{3}, 3.3(1.2$ and 8.9$)$ ppb, 20.5 (2.4 and 116.8) ppb, and 29 (16.7 and 42.8) ppb, respectively.

Figure 3 presents the predicted (kriging interpolated) air pollution concentrations for the 349 LAAs (kriging analysis details are presented in Additional file 1: Appendix 1, including the best-fit models and the estimated values of the ranges, sills, and nuggets for the various pollutants). Two major clusters of high $\mathrm{PM}_{2.5}$ levels were found in midwestern (5 LAAs in Yunlin County and 3 LAAs in Chiayi County) and southern (19 LAAs in Kaohsiung City and 6 LAAs in Pingtung County) Taiwan. Furthermore, the LAAs with high $\mathrm{PM}_{10}$ levels were widely distributed over southwestern Taiwan. In addition, three clusters of high $\mathrm{SO}_{2}$ levels were found in northern (8 LAAs in Taoyuan City and 4 LAAs in New Taipei City), midwestern (3 LAAs in Changhua County), and southern (18 LAAs in Kaohsiung City and 2 LAAs in Pingtung County) Taiwan. Moreover, two small clusters of high $\mathrm{NO}_{\mathrm{x}}$ levels were detected in northern (9 LAAs in Taipei City, 8 in New Taipei City, and 3 in Taoyuan City) and southern (12 LAAs in Kaohsiung City) Taiwan. Finally, LAAs with high $\mathrm{O}_{3}$ levels were found to be distributed across the main island of Taiwan.

Table 2 presents Spearman rank correlation coefficients between the age-adjusted cancer incidence rates and various air pollutants. A total of 17 correlation coefficients were significantly positive at an alpha level of 0.05 . Among these, the following four correlation coefficients between the age-adjusted cancer incidence rates and $\mathrm{PM}_{2.5}$ levels remained significant after Bonferroni

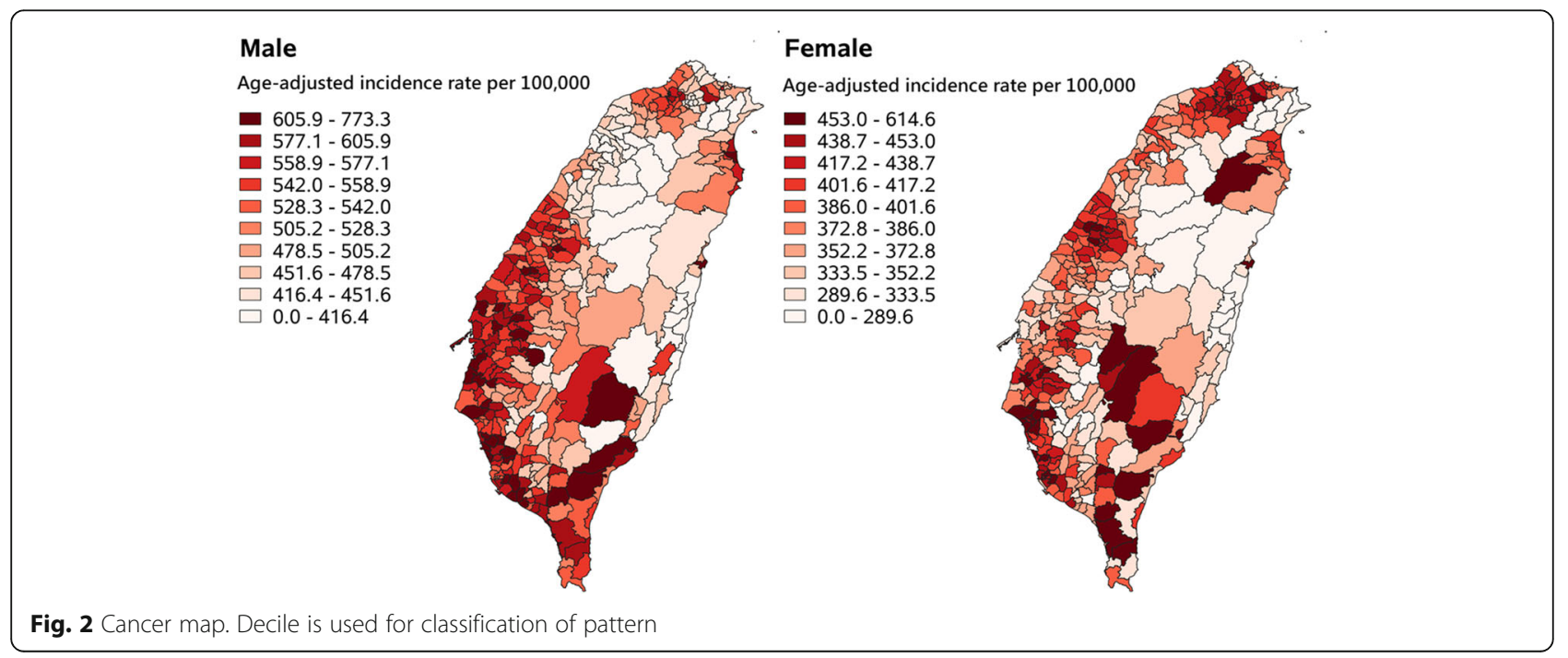


Table 1 Distribution of air pollution concentration from 2012 to 2016

\begin{tabular}{|c|c|c|c|c|c|c|c|c|}
\hline \multirow{2}{*}{$\begin{array}{l}\text { Air pollutant } \\
\text { (units) }\end{array}$} & \multirow[t]{2}{*}{ Mean (SD) } & \multirow[t]{2}{*}{ Minimum } & \multicolumn{5}{|c|}{ Percentiles } & \multirow[t]{2}{*}{ Maximum } \\
\hline & & & 5 th & 25th & 50th & 75th & 95th & \\
\hline $\mathrm{PM}_{2.5}\left(\mu \mathrm{g} / \mathrm{m}^{3}\right)$ & $25.182(7.502)$ & 6.280 & 12.297 & 20.189 & 25.109 & 29.803 & 39.255 & 45.380 \\
\hline $\mathrm{PM}_{10}\left(\mu \mathrm{g} / \mathrm{m}^{3}\right)$ & $49.500(13.615)$ & 15.690 & 28.400 & 39.316 & 48.454 & 59.708 & 72.443 & 81.931 \\
\hline $\mathrm{SO}_{2}(\mathrm{ppb})$ & $3.338(1.237)$ & 1.203 & 1.715 & 2.626 & 3.102 & 3.828 & 6.037 & 8.861 \\
\hline $\mathrm{NO}_{x}(\mathrm{ppb})$ & $20.470(14.044)$ & 2.374 & 7.749 & 13.601 & 17.726 & 23.215 & 37.012 & 116.787 \\
\hline $\mathrm{O}_{3}(\mathrm{ppb})$ & $28.952(3.726)$ & 16.677 & 23.026 & 26.729 & 28.734 & 31.053 & 36.035 & 42.777 \\
\hline
\end{tabular}

$\mathrm{SD}$ indicates standard deviation

$\mathrm{NO}_{\mathrm{x}}$ refers to the combination of $\mathrm{NO}$ and $\mathrm{NO}_{2}$

correction: the correlation coefficient of 0.60 in developing towns, 0.46 in general towns, 0.66 in aged towns for men, and 0.63 in aged towns for women.

Figure 4 presents the dose-response relationships of the Bonferroni-corrected significant associations. The ageadjusted cancer incidence rates for men in developing towns, general towns, and aged towns increased 13.1 (95\% confidence interval [CI], 8.8-17.6), 11 (95\% CI, 5.6-16.4), and 16.7 (95\% CI, 6.9-26.4) per 100,000 population, respectively, for every $1 \mu \mathrm{g} / \mathrm{m}^{3}$ increment in the $\mathrm{PM}_{2.5}$ concentration. In addition, the age-adjusted rate for women in aged towns increased 11.9 (95\% CI, 5.6-18.2) per 100, 000 population for every $1 \mu \mathrm{g} / \mathrm{m}^{3}$ increase in the $\mathrm{PM}_{2.5}$ concentration. Furthermore, the dose-response relationships for other significant associations at an alpha level of
0.05 (but not after Bonferroni correction) are presented in Additional file 1: Figure S1.

\section{Discussion}

This geographical association study revealed positive correlations between $\mathrm{PM}_{2.5}$ levels and age-adjusted cancer incidence rates, which remained significant after rigorous correction of multiple comparisons. $\mathrm{PM}_{2.5}$ can penetrate deeply into the lungs and other organs of the respiratory system [4]. According to WHO air quality guidelines, more than $95 \%$ of the monitored concentrations were higher than the annual permissible levels $\left(10 \mu \mathrm{g} / \mathrm{m}^{3}\right)$ in Taiwan. Moreover, according to the air quality criteria established by the Environmental Protection Administration in Taiwan

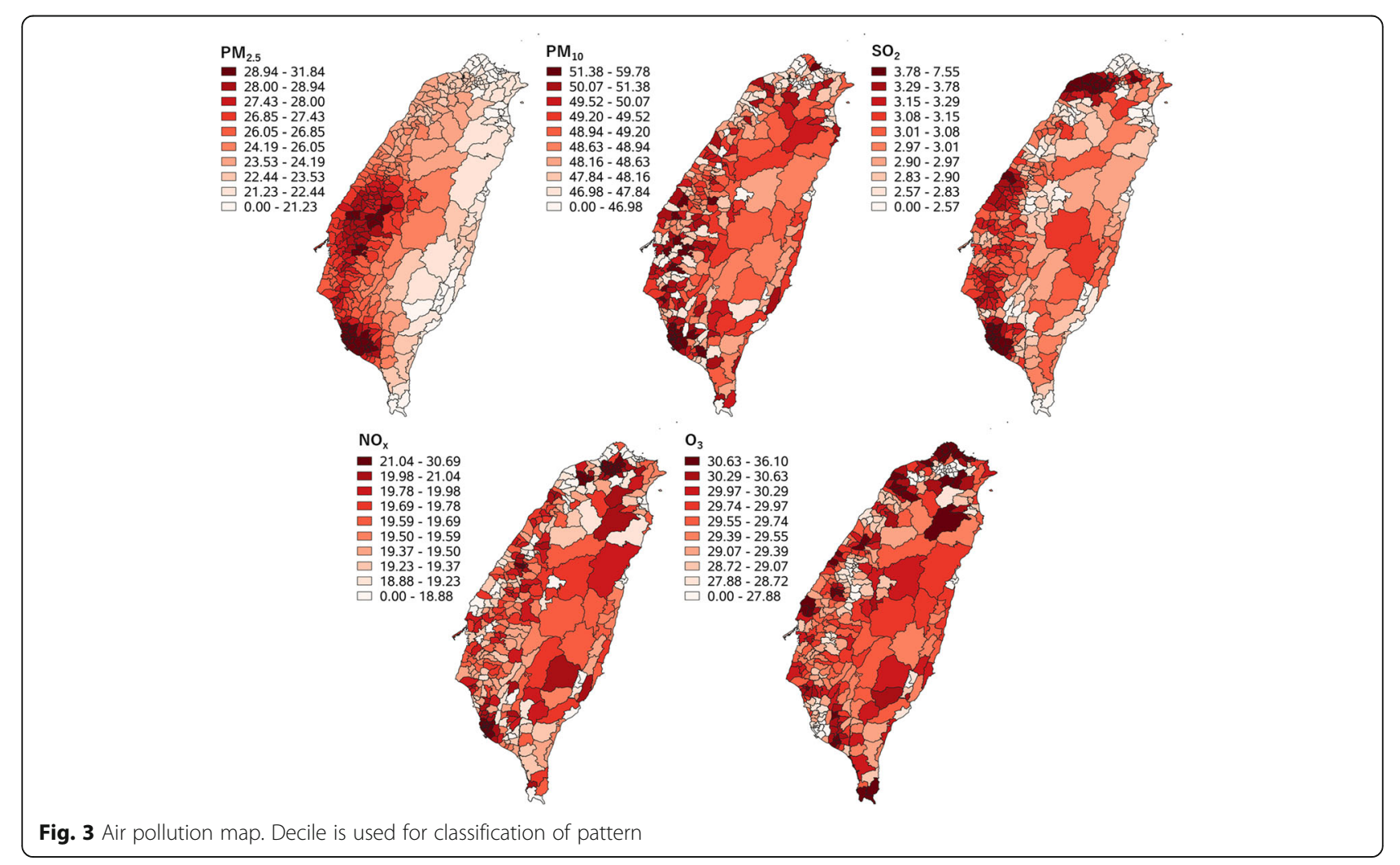


Table 2 Spearman's rank correlation coefficients between the age-adjusted cancer incidence rate and the various air pollutants by gender and urbanization degrees

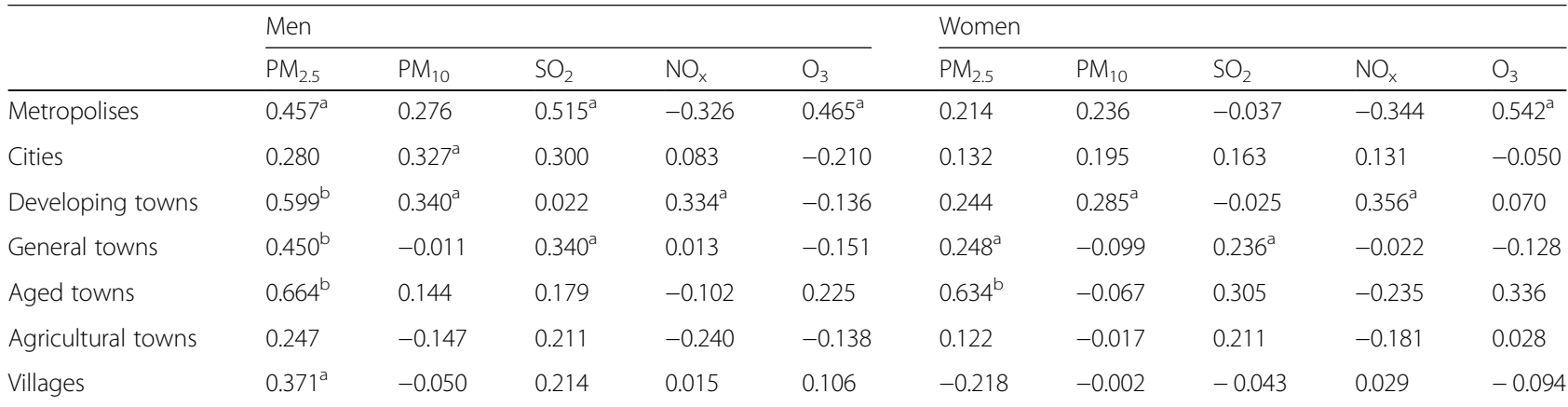

indicates significance at an alpha level of 0.05

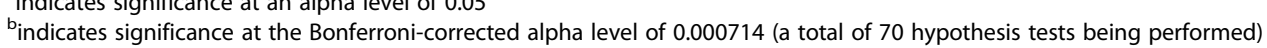

in 2012 , more than $75 \%$ of the monitored concentrations for the study period exceeded the annual permissible levels $\left(15 \mu \mathrm{g} / \mathrm{m}^{3}\right)$.

In Taiwan, the anthropogenic sources of $\mathrm{PM}_{2.5}$ include folk activities (incense, crop, firecracker, and firework burning), industrial activities (power plant, petrochemical, and nonpetrochemical), fugitive dust from roads and construction works, and traffic-related exhaust emissions [23], and the natural sources of $\mathrm{PM}_{2.5}$ include wildfires and river fugitive dust [24]. To understand the composition of air pollution, the Taiwanese government has implemented the Taiwan Emission Data System (TEDS) since 1992. According to a recent report of TEDS, the major sources of $\mathrm{PM}_{2.5}$ were fugitive dust from roads and construction works, traffic-related exhaust emissions, and industrial emissions (all anthropogenic emissions), which accounted for 41,23 , and $22 \%$, respectively, of the total emissions [25]. For the two clusters of $\mathrm{PM}_{2.5}$ (Fig. 3), 93, 90, 86, and $81 \%$ of the total emissions in Kaohsiung City, Yunlin County, Chiayi County, and Pingtung County were attributable to such anthropogenic emissions [25].

Our findings have added to the growing evidence of the negative consequence of $\mathrm{PM}_{2.5}$ on health. A recent report by IARC indicated that polluted air is a complex mixture of carcinogenic and mutagenic substances such as cigarette smoke and can widely affect the lungs and other organs [26, 27]. Exposure to $\mathrm{PM}_{2.5}$ can lead to inflammatory injury, immune response stress, oxidative DNA damage, DNA methylation, and insufficient DNA repair [28-32]. Such genotoxic effects may increase cancer risk [33].

Recent observational studies have revealed the harmful effect of $\mathrm{PM}_{2.5}$ on different cancer sites. According to a cohort study in the United States exploring the association of $\mathrm{PM}_{2.5}$ with mortality from 29 cancer sites, bladder and
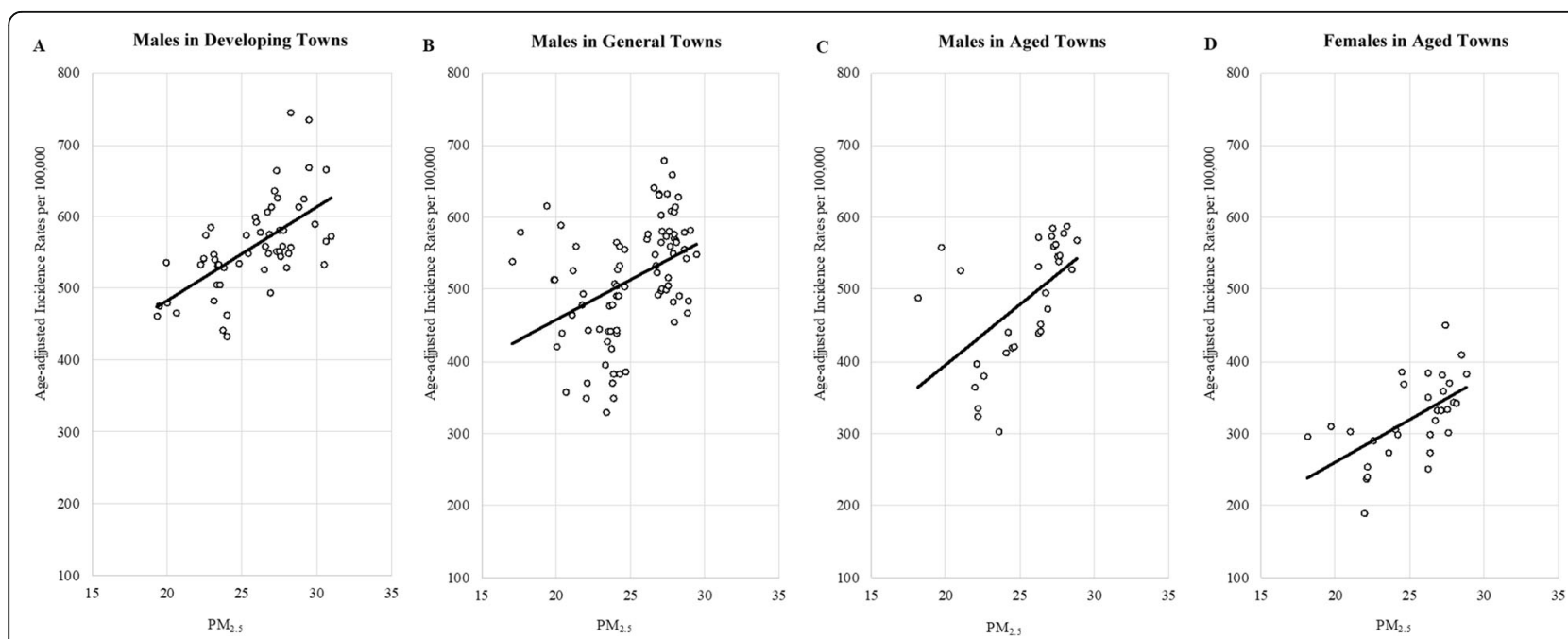

Fig. 4 Dose-response relationship of age-adjusted cancer incidence and fine particulate matter in developing towns (panel A), general towns (panel B) and aged towns (panel C) for males and aged towns (panel D) for females 
kidney cancers had significantly positive associations [5]. Another cohort study found that exposure to $\mathrm{PM}_{2.5}$ may increase liver cancer incidence in Europeans (although not statistically significant) [6]. Furthermore, previous studies in Taiwan have revealed that exposure to high $\mathrm{PM}_{2.5}$ levels was significantly associated with increased risks of lung, liver, breast, oral, and ovarian cancer [7-12]. We further examined the associations of $\mathrm{PM}_{2.5}$ with cancer types in developing, general, and aged towns and found significantly positive correlations with oral, colorectal, liver, and skin cancers (Additional file 1: Table S2). However, the negative correlation coefficients of gastric and renal cancers were significant after Bonferroni correction.

Aside from $\mathrm{PM}_{2.5}$, study also indicated significantly positive correlations (but not after Bonferroni correction) between other air pollutants $\left(\mathrm{PM}_{10}, \mathrm{SO}_{2}, \mathrm{NO}_{\mathrm{x}}\right.$, and $\mathrm{O}_{3}$ ) and age-adjusted cancer incidence rates. According to the report of TEDS, 93 and $89 \%$ of the total emissions for $\mathrm{PM}_{10}$ and $\mathrm{NO}_{\mathrm{x}}$, respectively, were attributable to fugitive dust from roads and construction works, trafficrelated exhaust emissions, and industrial emissions [25] (TEDS does not provide $\mathrm{SO}_{2}$ and $\mathrm{O}_{3}$ estimates). Studies have also suggested that air pollution due to pollutants other than $\mathrm{PM}_{2.5}$ is associated with an increased risk of lung, breast, prostate, and ovarian cancers [13-18].

We categorized each air pollutant into quartiles and calculated the population attributable fractions (PAFs) with the first (lowest) quartile as the baseline (Additional file 1: Table S3). The PAF due to $\mathrm{PM}_{2.5}$ was the largest; a total of $6.8 \%$ of cancer incidences can be attributable to high $\mathrm{PM}_{2.5}$ levels. Using the rate ratio estimates presented in Additional file 1: Table S3, we found that the PAFs due to $\mathrm{PM}_{2.5}$ were similar for men and women, and for the older (age, $\geq 60$ years) and young (age, $<60$ years) individuals. The PAFs due to $\mathrm{PM}_{2.5}$ were higher in rural areas (aged towns, agricultural towns, and villages) than in urban areas (metropolises, cities, developing towns, and general towns), $8.2 \%$ versus $6.7 \%$. For the geographical variations, the PAFs due to $\mathrm{PM}_{2.5}$ were $9.8,8.3,4.3$, and $3.6 \%$, respectively, for the southern, western, northern, and eastern parts of Taiwan. However, the aforementioned analyses assumed that the lag time between the exposures of air pollution and cancer incidence did not confound the estimations.

Reducing ambient air pollution is a control target of the sustainable development goals (SDGs) [34]. To meet the SDG of reducing air pollution caused by traffic exhaust emissions, planning a well-conceived transport strategy, reducing traffic congestion, and improving public transport networks are suggested. In Taiwan, a high correlation between $\mathrm{PM}_{2.5}$ concentrations and automobile usage was noted [7]. In December 2018, approximately 14 million motorcycles and 8 million cars (i.e., 58.6 motorcycles and 34.1 cars per 100 people, respectively) were registered in the Ministry of Transportation and Communications in Taiwan [35]. The Taiwanese government has implemented a policy of green incentives since 2009 to increase electric motorcycle production. In 2017, the market share of electric motorcycles manufactured in Taiwan accounted for $5.3 \%$ of global sales [36]. Another target of SDGs was to reduce the mortalities due to noncommunicable diseases (NCDs) by one-third. Cancer is one of the major NCDs. In this study, the highest cancer incidence rates were found in southwestern and midwestern Taiwan and were also significantly related to high $\mathrm{PM}_{2.5}$ levels. Therefore, reducing air pollution in such areas should be prioritized.

A number of limitations may compromise the study results. First, we standardized and stratified data to adjust for confounding effects due to age, gender, and urbanization. Possible confounding effects due to tobacco smoking, however, could not be adjusted for because of the lack of access to data. The Adult Smoking Behavior Survey implemented by the Ministry of Health and Welfare in Taiwan has investigated and collected the yearly cross-sectional data of smoking prevalence since 1997; however, the results were not detailed down to each LAA. Second, the air quality monitoring stations in Taiwan are purposely constructed near emission sources, such as densely populated areas, and downwind of industrial districts and dynamic traffic environments; however, all emission sources might not be covered by the monitoring stations, resulting in selection biases. Additional studies are needed to adjust for the confounding effect of smoking, and they should use a more accurate model, such as land-use regression [37], to clarify the association between ambient $\mathrm{PM}_{2.5}$ concentrations and cancer risk. Third, the five-year average cancer incidence rates were calculated to reduce random errors because many LAAs have small population sizes. Several LAAs in the central mountain range (Haiduan, Taoyuan, Yanping, Alishan, and Namasia) presented unusually high cancer incidence rates, possibly due to random errors resulting from the extremely small population size of these LAAs. Finally, this was an exploratory study based on aggregated data. An individual-level information such as body mass index, glycosylated hemoglobin, blood pressure, drug use, dietary pattern, and lifestyles is required for a finer confounding control. Further studies should combine the aggregated and the individual-level data in a hierarchical model to better clarify the associations between air pollutants and cancers.

\section{Conclusions}

The highest age-adjusted cancer incidence rates for both sexes and the hotspots of high $\mathrm{PM}_{2.5}$ levels were all located in southwestern and midwestern 
Taiwan. This geographical association study revealed significant positive correlations between $\mathrm{PM}_{2.5}$ concentrations and age-adjusted cancer incidence rates after multiple testing correction. Positive correlations for other air pollutants (i.e., $\mathrm{PM}_{10}, \mathrm{SO}_{2}, \mathrm{NO}_{\mathrm{x}}$, and $\mathrm{O}_{3}$ ) were also found, but not after Bonferroni correction. Additional studies are required to confirm or refute these findings.

\section{Supplementary information}

Supplementary information accompanies this paper at https://doi.org/10. 1186/s12889-019-7849-z.

Additional file 1: Appendix 1. Details of the kriging analysis. Figure

S1. The dose-response relationships for other significant associations under an alpha level of 0.05 but not after Bonferroni correction. Table S1. The smoking prevalence (\%) in Taiwan. Table S2. Further analysis of spearman correlation between $\mathrm{PM}_{2.5}$ and 21 cancer sites. Table S3. Population attributable fractions due to air pollutants.

\section{Abbreviations}

ASBS: Adult smoking behavior survey; EPA: Environmental protection administration; IARC: International agency for research on cancer; LAAs: Local administrative areas; $\mathrm{NO}_{2}$ : Nitrogen dioxide; $\mathrm{O}_{3}$ : Ozone; $\mathrm{PM}_{10}$ : Coarse particulate matter; $\mathrm{PM}_{2.5}$ : Fine particulate matter; SDGs: Sustainable Development Goals; $\mathrm{SO}_{2}$ : Sulphur dioxide; TEDS: Taiwan Emission Data System; WHO: World Health Organization

\section{Acknowledgements}

Not applicable.

\section{Authors' contributions}

WCL conceptualized the hypothesis for this paper and wrote the manuscript. YPL conceptualized the hypothesis for this paper. SYS analyzed the data and wrote the manuscript. JJR prepared the figures. SYH, CJC and YWY prepared the data. All authors read and approved the final version of the manuscript.

\section{Funding}

This paper is supported by grants from the Health Promotion Administration, the Ministry of Health and Welfare in Taiwan (A1051011; the tobacco control and health care funds), the Ministry of Science and Technology in Taiwan (MOST 105-2314-B-002-049-MY3, MOST 104-2314-B-002-118-MY3, and MOST 108-3017-F-002 -001; MOST 108-2314-B-002-127-MY3), and the Innovation and Policy Center for Population Health and Sustainable Environment (Population Health Research Center, PHRC) from Featured Areas Research Center Program within the framework of the Higher Education Sprout Project by the Ministry of Education (MOE) in Taiwan (grant number NTU108 L9003). No additional external funding was received for this study. The funders had no role in the study design, data collection and analysis, decision to publish, or preparation of the manuscript.

\section{Availability of data and materials}

The Taiwan Cancer Registry database is only available if any research institute has obtained permissions from the Department of Statistics, Ministry of Health and Welfare in Taiwan. For the cancer specific indices of the Taiwan Cancer Registry database, please refer to the link: https://cris.hpa.gov. tw/ (traditional Chinese only). For the application of the Taiwan Cancer Registry database usage, please contact the corresponding author (e-mail: wenchung@ntu.edu.tw) of this paper for more information.

\section{Ethics approval and consent to participate}

This study was approved by the Data Release Review Board of the Health Promotion Administration, Ministry of Health and Welfare in Taiwan, which waived the requirement for informed consent.

\section{Consent for publication}

Not applicable.

\section{Competing interests}

The authors declare that they have no competing interests.

\section{Author details}

${ }^{1}$ Institute of Epidemiology and Preventive Medicine, College of Public Health, National Taiwan University, Taipei, Taiwan. ${ }^{2}$ Innovation and Policy Center for Population Health and Sustainable Environment, College of Public Health, National Taiwan University, Taipei, Taiwan. ${ }^{3}$ Department of Public Health and Institute of Public Health, Chung Shan Medical University, Taichung, Taiwan.

${ }^{4}$ Taiwan Cancer Registry, Taipei, Taiwan.

Received: 12 June 2019 Accepted: 25 October 2019

Published online: 09 November 2019

\section{References}

1. World Health Organization. Regional Office for Europe. Air quality guidelines global update 2005 : particulate matter, ozone, nitrogen dioxide and sulfur dioxide. Copenhagen: WHO Regional Office for Europe; 2006. http://www. who.int/iris/handle/10665/107823

2. North CM, Rice MB, Ferkol T, Gozal D, Hui C, Jung SH, et al. Air pollution in the Asia-Pacific region. A joint Asian Pacific Society of Respirology/American Thoracic Society perspective. Am J Respir Crit Care Med. 2019;199(6):693-700.

3. Cicoira M. Ambient air pollution as a new risk factor for cardiovascular diseases: time to take action. Eur J Prev Cardiol. 2018;25(8):816-7.

4. Schraufnagel DE, Balmes JR, Cowl CT, De Matteis S, Jung SH, Mortimer K, et al. Air pollution and noncommunicable diseases: a review by the forum of international respiratory Societies' environmental committee, part 2: air pollution and organ systems. Chest. 2019;155(2):417-26.

5. Turner MC, Krewski D, Diver WR, Pope CA, Burnett RT, Jerrett M, et al. Ambient air pollution and cancer mortality in the cancer prevention study II. Environ Health Perspect. 2017;125(8):087013.

6. Pedersen M, Andersen ZJ, Stafoggia M, Weinmayre G, Galassi C, Sorensen M, et al. Ambient air pollution and primary liver cancer incidence in four European cohorts within the ESCAPE project. Environ Res. 2017;154:226-33.

7. Chiang PH, Chen C, Hsieh D, Chan TC, Chiang HC, Wen CP. Lung cancer risk in females due to exposures to PM2.5 in Taiwan. Open Epidemiol J. 2014;7:6-16.

8. Tseng CH, Tsuang BJ, Chiang CJ, Ku KC, Tseng JS, Yang TY, et al. The relationship between air pollution and Lung cancer in nonsmokers in Taiwan. J Thorac Oncol. 2019;14(5):784-92.

9. Pan WC, Wu CD, Chen MJ, Huang YT, Chen CJ, Su HJ, et al. Fine particle pollution, alanine transaminase, and liver cancer: a Taiwanese prospective cohort study (REVEAL-HBV). Jnci-J Natl Cancer I. 2016;108(3):1.

10. Hung LJ, Tsai SS, Chen PS, Yang YH, Liou SH, Wu TN, et al. Traffic air pollution and risk of death from breast cancer in Taiwan: fine particulate matter (PM2.5) as a proxy marker. Aerosol Air Qual Res. 2012;12(2):275-82.

11. Chu YH, Kao SW, Tantoh DM, Ko PC, Lan SJ, Liaw YP. Association between fine particulate matter and oral cancer among Taiwanese men. J Investig Med. 2019:67(1):34-8.

12. Hung LJ, Chan TF, Wu CH, Chiu HF, Yang CY. Traffic air pollution and risk of death from ovarian cancer in Taiwan: fine particulate matter (Pm2.5) as a proxy marker. J Toxicol Env Heal A. 2012;75(3):174-82.

13. Liaw YP, Ting TF, Ho KK, Yang CF. Cell type specificity of lung cancer associated with air pollution. Sci Total Environ. 2008;395(1):23-7.

14. Liu CC, Tsai SS, Chiu HF, Wu TN, Yang CY. Ambient exposure to criteria air pollutants and female lung cancer in Taiwan. Inhal Toxicol. 2008;20(3):311-7.

15. Tseng CY, Huang YC, Su SY, Huang JY, Lai CH, Lung CC, et al. Cell type specificity of female lung cancer associated with sulfur dioxide from air pollutants in Taiwan: an ecological study. BMC Public Health. 2012;12:4.

16. Hystad P, Villeneuve PJ, Goldberg MS, Crouse DL, Johnson K, Epidemiol CCR Exposure to traffic-related air pollution and the risk of developing breast cancer among women in eight Canadian provinces: a case-control study. Environ Int. 2015;74:240-8.

17. Shekarrizfard M, Valois MF, Weichenthal S, Goldberg MS, Fallah-Shorshani M, Cavellin LD, et al. Investigating the effects of multiple exposure measures to traffic-related air pollution on the risk of breast and prostate cancer. J Transp Health. 2018;11:34-46.

18. Vieira VM, Villanueva C, Chang J, Ziogas A, Bristow RE. Impact of community disadvantage and air pollution burden on geographic disparities of ovarian cancer survival in California. Environ Res. 2017;156:388-93.

19. Cohen AJ, Brauer M, Burnett R, Anderson HR, Frostad J, Estep K, et al. Estimates and 25-year trends of the global burden of disease attributable to 
ambient air pollution: an analysis of data from the global burden of diseases study 2015. Lancet. 2017:389(10082):1907-18.

20. Loomis D, Huang W, Chen GS. The International Agency for Research on Cancer (IARC) evaluation of the carcinogenicity of outdoor air pollution: focus on China. Chin J Cancer. 2014;33(4):189-96.

21. Bayraktar $\mathrm{H}$, Turalioglu FS. A kriging-based approach for locating a sampling site - in the assessment of air quality. Stoch Env Res Risk A. 2005;19(4):301-5.

22. Liu CY, Hung YT, Chuang YL, Chen YJ, Weng WS, Liu JS, et al. Incorporating development stratification of Taiwan townships into sampling Design of Large Scale Health Interview Survey. J Health Manag. 2006;4(1):1-22.

23. Lu HY, Wu YL, Mutuku JK, Chang KH. Various sources of PM2.5 and their impact on the air quality in Tainan City, Taiwan. Aerosol Air Qual Res. 2019; 19(3):601-19.

24. Hsu CY, Chiang HC, Chen MJ, Chuang CY, Tsen CM, Fang GC, et al. Ambient PM2.5 in the residential area near industrial complexes: spatiotemporal variation, source apportionment, and health impact. Sci Total Environ. 2017; 590:204-14.

25. TEDS-9.0, Taiwan Emission Data System Version 9.0, Environmental Protection Administration, Taipei, Taiwan, Republic of China (2016). https:// teds.epa.gov.tw/TEDS.aspx. (Accessed 18 April 2017).

26. IARC. Diesel and gasoline engine exhausts and some nitroarenes. IARC Monogr Eval Carcinog Risk Hum. 2012;105:1-714 https://monographs.iarc.fr/ ENG/Monographs/vol105/mono105.pdf. (Accessed 4 June 2016).

27. IARC. Outdoor air pollution. IARC Monogr Eval Carcinog Risk Hum. 2013;109: 1-454 https://monographs.iarc.fr/ENG/Monographs/vol109/mono109-F01. pdf (Accessed 19 March 2016)

28. Sorensen M, Autrup H, Moller P, Hertel O, Jensen SS, Vinzents P, et al. Linking exposure to environmental pollutants with biological effects. Mutat Res-Rev Mutat. 2003;544(2-3):255-71.

29. Gabelova A, Valovicova Z, Horvathova E, Slamenova D, Binkova B, Sram RJ, et al. Genotoxicity of environmental air pollution in three European cities: Prague, Kosice and Sofia. Mutat Res-Gen Tox En. 2004;563(1):49-59.

30. Danielsen PH, Risom L, Wallin H, Autrup H, Vogel U, Loft S, et al. DNA damage in rats after a single oral exposure to diesel exhaust particles. Mutat Res-Fund Mol M. 2008;637(1-2):49-55.

31. Valavanidis A, Fiotakis K, Vlachogianni T. Airborne particulate matter and human health: toxicological assessment and importance of size and composition of particles for oxidative damage and carcinogenic mechanisms. J Environ Sci Heal C. 2008;26(4):339-62.

32. DeMarini DM. Genotoxicity biomarkers associated with exposure to traffic and near-road atmospheres: a review. Mutagenesis. 2013;28(5):485-505.

33. Bernstein C, Prasad AR, Nfonsam V, Bernstein H. DNA damage, DNA repair and cancer, new research directions in DNA repair, Clark Chen, IntechOpen; 2013. https://doi.org/10.5772/53919. Available from: https://www. intechopen.com/books/new-research-directions-in-dna-repair/dna-damagedna-repair-and-cancer

34. Prüss-Üstün A, Wolf J, Corvalán CF, Bos R, Neira MP. Preventing disease through healthy environments: a global assessment of the burden of disease from environmental risks. Geneva: World Health Organization; 2016. http://www.who.int/iris/handle/10665/204585

35. Department of Statistics of Ministry of Transportation and Communications. The Statistics of Transportation \& Communications. Ministry of Transportation and Communications. 2019;608:1-258 https://www.motc. gov.tw/uploaddowndoc?file=mebook/201903111612300.pdf\&filedisplay= 10801 book.pdf\&flag=doc. (Accessed 11 March 2019).

36. Huang SK, Kuo L, Chou KL. The impacts of government policies on green utilization diffusion and social benefits - a case study of electric motorcycles in Taiwan. Energ Policy. 2018;119:473-86.

37. Mercer LD, Szpiro AA, Sheppard L, Lindstrom J, Adar SD, Allen RW, et al. Comparing universal kriging and land-use regression for predicting concentrations of gaseous oxides of nitrogen (NOx) for the multi-ethnic study of atherosclerosis and air pollution (MESA air). Atmos Environ. 2011; 45(26):4412-20.

\section{Publisher's Note}

Springer Nature remains neutral with regard to jurisdictional claims in published maps and institutional affiliations.

\section{Ready to submit your research? Choose BMC and benefit from:}

- fast, convenient online submission

- thorough peer review by experienced researchers in your field

- rapid publication on acceptance

- support for research data, including large and complex data types

- gold Open Access which fosters wider collaboration and increased citations

- maximum visibility for your research: over $100 \mathrm{M}$ website views per year

At BMC, research is always in progress.

Learn more biomedcentral.com/submissions 